\title{
Multi-criteria analysis of building assessment regarding energy performance using a life-cycle approach
}

\author{
Silvia Vilcekova • Eva Kridlova Burdova
}

Received: 16 July 2013/ Accepted: 27 January 2014/Published online: 4 April 2014

(C) The Author(s) 2014. This article is published with open access at Springerlink.com

\begin{abstract}
The sustainability assessment methods used over the world were the basis of new system development for Slovak conditions. The proposed fields are site selection and project planning; building construction; indoor environmental quality; energy performance; water and waste management. The evaluated indicators were proposed on the basis of available information analysis from particular fields of building environmental assessment and also on the basis of our experimental experiences. The aim of this paper is to present developed building environmental assessment system oriented to energy performance and the significance weight determination. Percentage weight of fields and indicators was determined on the basis of their significance, according to mathematical method.
\end{abstract}

Keywords Buildings - Energy performance ·

Environmental assessment

\section{Introduction}

Buildings are associated with large environmental impacts over a long duration. They consume an enormous amount of energy and other resources, and they contribute to carbon emissions at each stage of the building project, from design and construction through operation and finally to demolition $[1,2]$. The identification of the building sector

5th International Congress on Energy and Environmental Engineering and Management (CIIEM).

S. Vilcekova $(\square) \cdot$ E. Kridlova Burdova

Institute of Environmental Engineering, Faculty of Civil

Engineering, Technical University of Kosice, Vysokoskolska 4,

04200 Kosice, Slovak Republic

e-mail: silvia.vilcekova@tuke.sk as one of the key consumers of energy led to the creation of some rules targeted at improving the energy performance of buildings down to nearly zero through the reduction of energy consumption during the occupation phase [3]. This energy consumption for a building is considered to be the energy used to maintain the occupants' comfort inside the building (energy for heating, cooling, lighting, etc.). When taking the entire building life cycle into account, total energy used includes operational and embodied energy [4]. The assessment of energy performance of buildings is very important for achieving sustainable development. The aim of the building environmental assessment tools is to provide a sustainable building design, construction, operation, maintenance and renovation, which require cooperation between civil engineers, architects, designers, environmentalists and other experts from different areas of building performance. The relatively new approach of making a sustainability assessment of buildings requires the quantification of impacts and aspects of the environmental, social and economic performance of buildings using quantitative and qualitative indicators. These indicators are included in systems and tools used in various countries for the integrated assessment of buildings. The Slovak building environmental assessment system (BEAS) involves the evaluation of the following fields: site selection and project planning, building construction, the indoor environment, energy performance, water management and waste management [5]. Life-cycle assessment (LCA) belongs to a broadly used methodology which helps with decisionmaking on sustainable building design. The significance of LCA lies in the fact that it equips policy makers and decision makers for the adoption of suitable and sustainable energy supply systems. Increasing global concern about air pollution and limited oil reserves has generated a great deal of interest in environmentally friendly 
alternatives [6, 7]. Many works studied problems of lifecycle assessment of concrete through a variety of environmental indicators $[8,9]$. The goals of energy performance are: to reduce total building energy consumption and peak electrical demand; to reduce air pollution, contributions to global warming and ozone depletion caused by energy production; to slow down the depletion of fossil fuel reserves; and to lower energy costs and gain related savings due to upgrades to infrastructure. Energy consumption in buildings takes place in two different ways: energy capital that goes into the production and transportation of building materials and the assembling of the building itself (embodied energy), and the energy needed to maintain the building during its useful life. This paper deals with the proposal of a building environmental assessment system, especially one dealing with the assessment and weighting of the energy performance of buildings in Slovakia.

\section{Energy performance of buildings}

Within the European Union (EU) energy use by the built environment represents more than $40 \%$ of total energy consumption $[10,11]$, with attention paid to energy and the environment currently growing in the everyday political agenda, even at a local level. As pointed out in the Agenda 21 document approved at the Rio Conference in 1992, local administrations can play a fundamental role in increasing sustainability by acting according to the well-known motto "think globally, act locally"; the inspiring principles of the Local A21 process are a suitable tool for designing a strategic road map to sustainability [12]. In line with the European Union's Energy Performance of Buildings Directive (EPBD), all new buildings within the union must be nearly zero-energy by the end of 2020 [10]. To quantify the effect of energy-saving measures in the built environment, different methodologies with accompanying indicators have been, and still are being developed. Because of the European EPBD [13], many indicators have been developed to express the energy performance of European buildings through use of an energy label with a classification system with grades from A to G. Now that Energy Performance Certification is compulsory within the European Union, it might be useful to relate the value of real estate objects to the life-cycle costs of energy-saving measures [12]. Promotion of energy efficiency is one of the main goals of energy policies since it improves resource management and reduces energy use and environmental impacts. Today most developed nations include a section on energy efficiency within their energy planning policies, usually implemented through a series of laws, codes, strategies, regulations and certification schemes [14].
Table 1 shows the most significant and globally used building environmental assessment systems [15-23] and main fields related to energy assessment.

\section{Environmental assessment system of buildings in Slovakia}

In recent years, the evaluation of building performance in terms of environmental, social and economic aspects has become a topic of discussion in the Slovak Republic. A new Building Environmental Assessment System (BEAS) has been developed at the Institute of Environmental Engineering, Technical University of Košice. Systems and tools used in many other countries were the foundation of this new system developed for application in Slovak conditions. The main fields and relevant indicators of BEAS were proposed on the basis of available information from particular fields of building performance in Slovakia and also according to our own experimental experience. BEAS as a multi-criteria system includes environmental, social and cultural aspects. The proposed fields and indicators respect and adhere to Slovak standards, rules, studies and experiments. The presented system was developed for use during the design stage of office buildings. This system for Slovakia contains 6 main fields and 52 indicators. For the purpose of system weighting, the analytical hierarchy process (AHP) was used [5]. The hierarchy structure of BEAS is shown in Table 2.

The proposed main fields are: $\mathrm{A}-$ site selection and project planning, $\mathrm{B}$-building construction, $\mathrm{C}$-indoor environment, D-energy performance, E-water management, and $\mathrm{F}$-waste management.

The methodology for the derivation of the assessment indicators in BEAS was elaborated according to a study [24] and the list of indicators derived through a threestep process. To establish a comprehensive set of indicators for this method of building environmental assessment for office buildings, existing methods of building environmental assessment used worldwide were combined with valid Slovak standards and codes and an academic research paper. A three-step process was carried out. In the first step, a full range of indicators relating to sustainable building efficiency were collected through an extensive review of the literature. In step two, a draft indicator list was selected from the full indicator list based on an in-depth analysis, and in step three, a survey was conducted to gather comments from experts to refine the selected draft indicators. As a result, a final indicator list was then proposed. This list is presented for the field of energy performance in the following sections of this paper. 
Table 1 Energy performance field in the most significant building environmental assessment systems

\begin{tabular}{|c|c|c|c|}
\hline System & Energy performance field & Weight (\%) & Indicators \\
\hline BREEAM & Energy & 19 & $\begin{array}{l}\text { Reduction of } \mathrm{CO}_{2} \text { emissions } \\
\text { Energy monitoring } \\
\text { Energy efficient external lighting } \\
\text { Low or zero carbon technologies } \\
\text { Energy efficient cold storage } \\
\text { Energy efficient transportation systems } \\
\text { Energy efficient laboratory systems } \\
\text { Energy efficient equipment (process) } \\
\text { Drying space }\end{array}$ \\
\hline Green Globes & Energy & 38 & $\begin{array}{l}\text { Energy performance } \\
\text { Reduced energy demand } \\
\text { Integration of energy efficient systems } \\
\text { Renewable energy sources } \\
\text { Energy efficient transportation }\end{array}$ \\
\hline SBTool & $\begin{array}{l}\text { ENERGY and resource } \\
\text { consumption }\end{array}$ & 22.5 & $\begin{array}{l}\text { Total life cycle non-renewable energy } \\
\text { Electrical peak demand for facility operations } \\
\text { Renewable energy } \\
\text { Materials } \\
\text { Potable water }\end{array}$ \\
\hline LEED & Energy and atmosphere & 36.4 & $\begin{array}{l}\text { Regional materials } \\
\text { Rapidly renewable materials } \\
\text { Certified wood }\end{array}$ \\
\hline CASBEE & Energy & 20 & $\begin{array}{l}\text { Building thermal load } \\
\text { Natural energy utilisation } \\
\text { Efficiency in building service system } \\
\text { Efficient operation }\end{array}$ \\
\hline BEAM & Energy use & 41.3 & $\begin{array}{l}\text { Annual energy use } \\
\text { Energy efficient systems } \\
\text { Energy efficient equipment } \\
\text { Provisions for energy management } \\
\text { Building design for energy efficiency }\end{array}$ \\
\hline SABA & Energy efficiency & 23.1 & $\begin{array}{l}\text { Building envelope performance } \\
\text { Renewable energy } \\
\text { Natural lighting/lighting } \\
\text { Energy efficient heating/cooling system } \\
\text { Mechanic systems } \\
\text { Greenhouse gases emission } \\
\text { Machines/appliances }\end{array}$ \\
\hline Estidama & Resourceful energy & 26.4 & $\begin{array}{l}\text { Community energy strategy } \\
\text { Building guidelines } \\
\text { Energy monitoring and reporting } \\
\text { Community strategies for passive cooling } \\
\text { Urban heat reduction } \\
\text { Efficient infrastructure } \\
\text { Renewable energy: onsite, offsite } \\
\text { Energy efficient buildings }\end{array}$ \\
\hline
\end{tabular}


Significance weighting of the energy performance field

Multi-criteria decision analysis (MCDA) through mathematical methods can help clarify choices between alternative solutions based on many, often conflicting, criteria and aspects. It seeks to integrate several goals to arrive at the most suitable solution, considering along the way the relative importance of each goal, and offers the possibility of developing a deeper understanding of the problem. If necessary, a section is dedicated to the experimental part, where the teams and means used to develop the work are briefly described [25, 26].

The significance weights of the energy performance field and indicators were determined using the

Table 2 Hierarchy structure of BEAS

\begin{tabular}{|c|c|c|c|c|c|c|c|c|c|}
\hline \multicolumn{10}{|l|}{ BEAS } \\
\hline \multicolumn{2}{|l|}{ A } & \multicolumn{2}{|l|}{ B } & \multirow{2}{*}{$\frac{\mathrm{C}}{\mathrm{C} 1}$} & \multicolumn{3}{|l|}{ D } & \multirow{2}{*}{$\frac{E}{E 1}$} & \multirow{2}{*}{$\frac{F}{F 1}$} \\
\hline A1 & $\mathrm{A} 2$ & B1 & B2 & & D1 & D2 & D3 & & \\
\hline A1.1 & A2.1 & B2.1 & B2.1 & $\mathrm{C} 2$ & D1.1 & D2.1 & D3.1 & E2 & $\mathrm{F} 2$ \\
\hline A 1.2 & A 2.2 & B2.2 & B2.2 & $\mathrm{C} 4$ & D1.2 & D2.2 & D3.2 & E3 & F3 \\
\hline A 1.3 & A 2.3 & B2.3 & B2.3 & C5 & D1.3 & D2.3 & & E4 & \\
\hline A1.4 & A2.4 & B2.4 & & C6 & D1.4 & & & & \\
\hline A1.5 & A2.5 & B2.5 & & C7 & D1.5 & & & & \\
\hline A1.6 & A2.6 & & & C8 & & & & & \\
\hline A1.7 & A2.7 & & & C9 & & & & & \\
\hline A1.8 & & & & C10 & & & & & \\
\hline A1.9 & & & & & & & & & \\
\hline A 1.10 & & & & & & & & & \\
\hline
\end{tabular}

Table 3 Saaty matrix of field D-energy performance

\begin{tabular}{llllllll}
\hline$a(i, j)$ & \multicolumn{2}{l}{ Criteria } & & $P(i, j)$ & $R(i)$ & $v(i)$ & $\begin{array}{l}\text { Weights } \\
(\%)\end{array}$ \\
\cline { 2 - 5 } Criteria & D1 & D2 & D3 & & & & \\
\hline D1 & 1.00 & 5.50 & 2.00 & 11 & 2.224 & 0.692 & 69.2 \\
D2 & 0.18 & 1.00 & 1.00 & 0.181818 & 0.567 & 0.176 & 17.6 \\
D3 & 0.15 & 0.50 & 1.00 & 0.076923 & 0.425 & 0.132 & 13.2 \\
Total & & & & & 3.780 & 1.000 & 100 \\
\hline
\end{tabular}

mathematical analytic hierarchy process (AHP), the Saaty method and the pairwise comparison method (the Fuller method). Determined weights of significance were analysed and compared with weights of significance determined in various other systems used around the world. On the basis of comparison and consistent analysis of several variants, the most suitable variant was determined by the Saaty method. In Table 3, an example of field D-energy performance weighting by Saaty-is presented. The criteria weights were determined using the Saaty matrix, a concrete example of which is in the first part of the table with rows and columns marked D1, D2, D3. Di means the $i$ th criterion of $\mathrm{D}$-energy performance weighting for $i=1,2,3$. The values of the Table 2 in columns $P(i), R(i)$, $v(i)$ were computed using the following Eqs. (1-3). In the last column of the table are percentage weights of assessment criteria. The weights of all assessment criteria in main field D-energy performance-were determined using the same method and all computed values are given in Tables 3, 4, 5, and 6 .

$P(i)=\prod_{j=1}^{n} a(i, j)$

$R(i)=\sqrt[n]{P(i)}$

$v(i)=\frac{R(i)}{\sum_{i=1}^{n} R(i)}$

where $n$ is the dimension of the Saaty matrix, $a(i, j)$ the element of the Saaty matrix of $i$ th row and $j$ th column, $P(i)$ the product of all elements of the Saaty matrix $i$ th row, $R(i)$ the quadratic average of the Saaty matrix $i$ th row and $v(i)$ the weight of $i$ th criterion

In Tables 4, 5, and 6, the weighting of indicators in the subfields are presented:

- D1-operation energy,

- D2-active systems using renewable energy sources and

- D3-energy management.

The criteria weights were assigned using the Saaty matrix.
Table 4 Saaty matrix of subfield D1-operation energy

\begin{tabular}{llllllllll}
\hline$a(i, j)$ & \multicolumn{1}{l}{ Criteria } & \multicolumn{1}{c}{} & & $P(i, j)$ & $R(i)$ & $v(i)$ & Weights $(\%)$ \\
\cline { 2 - 6 } Criteria & D1.1 & D1.2 & D1.3 & D1.4 & D1.5 & & & & \\
\hline D1.1 & 1.00 & 2.00 & 3.50 & 5.00 & 5.00 & 175 & 2.809 & 0.438 & 43.8 \\
D1.2 & 0.50 & 1.00 & 3.50 & 4.00 & 4.00 & 28 & 1.947 & 0.304 & 30.4 \\
D1.3 & 0.29 & 0.29 & 1.00 & 2.00 & 2.00 & 0.163265 & 0.696 & 0.109 & 10.9 \\
D1.4 & 0.20 & 0.25 & 0.50 & 1.00 & 1.00 & 0.025 & 0.478 & 0.075 & 7.5 \\
D1.5 & 0.20 & 0.25 & 0.50 & 1.00 & 1.00 & 0.025 & 0.478 & 0.075 & 7.5 \\
Total & & & & & & & 5.801 & 1.000 & 100 \\
\hline
\end{tabular}


Table 5 Saaty matrix of subfield D2-active systems using renewable energy sources

\begin{tabular}{lllllllll}
\hline $\mathrm{a}(i, j)$ & Criteria & \multicolumn{1}{c}{} & & $P(i, j)$ & $R(i)$ & $v(i)$ & Weights $(\%)$ \\
\cline { 2 - 5 } Criteria & $\mathrm{D} 2.1$ & $\mathrm{D} 2.2$ & $\mathrm{D} 2.3$ & $\mathrm{D} 2.4$ & & & & \\
\hline $\mathrm{D} 2.1$ & 1.00 & 2.00 & 1.00 & 1.00 & 2 & 1.260 & 0.413 & 53.5 \\
$\mathrm{D} 2.2$ & 0.50 & 1.00 & 1.00 & 0.50 & 0.5 & 0.794 & 0.260 & 16.5 \\
$\mathrm{D} 2.3$ & 1.00 & 1.00 & 1.00 & 1.00 & 1 & 1.000 & 0.327 & 22 \\
Total & & & & & & 3.054 & 1.000 & 100 \\
\hline
\end{tabular}

The significant weights of the criteria were determined using various methods presented in Table 7 . The determined weights of significance were analysed and compared with weights of significance determined in various systems used around the world. On the basis of comparison and consistent analysis of four variants, the most suitable variant is that determined by the MCA— the Saaty method.

\section{Results and discussions}

According to the presented methodology for derivation of indicators for assessment and significance weighting, the percentage weights and the means of the assessment of indicators related to energy performance of buildings are presented in Table 8 .

Table 6 Saaty matrix of subfield D3-energy management

\begin{tabular}{|c|c|c|c|c|c|c|}
\hline \multirow{2}{*}{$\begin{array}{l}\mathrm{a}(i, j) \\
\text { Criteria }\end{array}$} & \multicolumn{2}{|c|}{ Criteria } & \multirow[t]{2}{*}{$P(i, j)$} & \multirow[t]{2}{*}{$R(i)$} & \multirow[t]{2}{*}{$v(i)$} & \multirow[t]{2}{*}{ Weights (\%) } \\
\hline & D3.1 & D3.2 & & & & \\
\hline D3.1 & 1.00 & 1.00 & 1 & 1.000 & 0.500 & 50 \\
\hline D3.2 & 1.00 & 1.00 & 1 & 1.000 & 0.500 & 50 \\
\hline Total & & & & 2.000 & 1.000 & 100 \\
\hline
\end{tabular}

In this paper, the indicators related to the field of energy performance and method for determining the significance weight of this field in BEAS are presented. The percentage weights for energy performance field in the significant environmental assessment systems vary from 19 to $41.3 \%$, the lowest significant weight of $19 \%$ for BREEAM and the highest of $41.3 \%$ for BEAM. Energy performance in BEAS has a percentage weight of $26.45 \%$, which corresponds with the mean percentage weight of $28.33 \%$ determined for selected significant systems used in the world (Table 1). The field of energy performance in BEAS consists of 3 subfields and 11 indicators. Within this field the subfield, D1-operational energy has a weight of $56.25 \%$, the second subfield, D2-active systems using renewable energy sources has $25 \%$ and the third subfield, D3-energy management has $18.75 \%$.

\section{Conclusions}

Building environmental assessment systems and tools has been developed for various types of buildings and for each stage of their life cycle, comparison of the methods and tools developed in different countries showing that these systems are quite diverse. At the same time, however, we

Table 7 Significant weights of criteria using various methods

\begin{tabular}{|c|c|c|c|c|c|}
\hline & & $\begin{array}{l}\text { MCA-Saaty } \\
(\%)\end{array}$ & $\begin{array}{l}\text { MCA-Fuller } \\
(\%)\end{array}$ & $\begin{array}{l}\text { MCA-geometric } \\
\text { mean line }(\%)\end{array}$ & $\begin{array}{l}\text { Saaty } \\
\text { matrix }(\%)\end{array}$ \\
\hline $\mathrm{D}$ & Energy performance & 26.45 & 32.69 & 22.5 & 27.99 \\
\hline D1 & Operation energy & 56.25 & 63.64 & 42.86 & 69.16 \\
\hline D1.1 & Energy for heating & 23.08 & 29.52 & 23.08 & 43.83 \\
\hline D1.2 & Energy for domestic hot water & 23.08 & 29.52 & 23.08 & 30.38 \\
\hline D1.3 & Energy for mechanical ventilation and cooling & 23.08 & 29.52 & 23.08 & 10.86 \\
\hline D1.4 & Energy for lighting & 17.59 & 10.48 & 17.95 & 7.46 \\
\hline D1.5 & Energy for appliances & 12.82 & 0.95 & 12.82 & 7.46 \\
\hline D2 & Active systems using renewable energy sources & 25 & 33.33 & 33.33 & 17.62 \\
\hline D2.1 & Solar system and/or photovoltaic technology & 36 & 63.64 & 36 & 53.5 \\
\hline D2.2 & Technology for renewable energy other than solar energy & 32 & 18.18 & 32 & 16.5 \\
\hline D2.3 & Heat recuperation & 32 & 18.18 & 32 & 22 \\
\hline D3 & Energy management & 18.75 & 3.03 & 23.81 & 13.23 \\
\hline D3.1 & Energy management system & 50 & 50 & 50 & 50 \\
\hline D3.2 & Facility management & 50 & 50 & 50 & 50 \\
\hline
\end{tabular}


Table 8 Means of assessment of energy performance

\begin{tabular}{|c|c|c|c|}
\hline $\mathrm{D}$ & Energy performance & & $26.45 \%$ \\
\hline D1 & Operation energy & & $56.25 \%$ \\
\hline D1.1 & Energy for heating & & $23.08 \%$ \\
\hline Intent & To determine energy needs for heating & Score & Weight \\
\hline Indicator & \multicolumn{3}{|c|}{$\begin{array}{l}\text { Class of energy for heating according to energy performance of buildings } \\
\text { directive (EPBD) and related standards. }\end{array}$} \\
\hline Negative & \multicolumn{2}{|c|}{ Energy for heating is in a class lower than $\mathrm{C}$. } & -1 \\
\hline Acceptable practice & \multicolumn{2}{|l|}{ Energy for heating is in class $\mathrm{C}$. } & 0 \\
\hline Good practice & \multicolumn{2}{|l|}{ Energy for heating is in class B. } & 3 \\
\hline Best practice & \multicolumn{2}{|l|}{ Energy for heating is in class A. } & 5 \\
\hline D1.2 & Energy for domestic hot water & & $23.08 \%$ \\
\hline Intent & To determine energy needs for domestic hot water. & Score & Weight \\
\hline Indicator & \multicolumn{3}{|c|}{$\begin{array}{l}\text { Class of energy for domestic hot water according to standards for energy } \\
\text { performance of buildings. }\end{array}$} \\
\hline Negative & \multicolumn{2}{|c|}{ Energy for domestic hot water is in a class lower than $\mathrm{C}$. } & -1 \\
\hline Acceptable practice & \multicolumn{2}{|l|}{ Energy for domestic hot water is in class $\mathrm{C}$. } & 0 \\
\hline Good practice & \multicolumn{2}{|l|}{ Energy for domestic hot water is in class B. } & 3 \\
\hline Best practice & \multicolumn{2}{|l|}{ Energy for domestic hot water is in class A. } & 5 \\
\hline D1.3 & \multirow{2}{*}{$\begin{array}{l}\text { Energy for mechanical ventilation and cooling } \\
\text { To determine energy needs for mechanical ventilation and } \\
\text { cooling. }\end{array}$} & & $23.08 \%$ \\
\hline Intent & & Score & Weight \\
\hline Indicator & \multicolumn{3}{|c|}{$\begin{array}{l}\text { Class of energy for mechanical ventilation and cooling according to standards } \\
\text { for energy performance of buildings. }\end{array}$} \\
\hline Negative & \multicolumn{2}{|c|}{$\begin{array}{l}\text { Energy for mechanical ventilation and cooling is in a class lower } \\
\text { than C. }\end{array}$} & -1 \\
\hline Acceptable practice & \multicolumn{2}{|c|}{ Energy for mechanical ventilation and cooling is in class $\mathrm{C}$. } & 0 \\
\hline Good practice & \multirow{2}{*}{\multicolumn{2}{|c|}{ Energy for mechanical ventilation and cooling is in class B. }} & 3 \\
\hline Best practice & & & 5 \\
\hline D1.4 & Energy for lighting & & $17.59 \%$ \\
\hline Intent & To determine energy needs for lighting. & Score & Weight \\
\hline Indicator & \multicolumn{3}{|c|}{$\begin{array}{l}\text { Class of energy for lighting according to standards for energy performance of } \\
\text { buildings. }\end{array}$} \\
\hline Negative & \multicolumn{2}{|c|}{ Energy for lighting is in a class lower than $\mathrm{C}$. } & -1 \\
\hline Acceptable practice & \multicolumn{2}{|l|}{ Energy for lighting is in class $\mathrm{C}$. } & 0 \\
\hline Good practice & \multicolumn{2}{|l|}{ Energy for lighting is in class B. } & 3 \\
\hline Best practice & \multicolumn{2}{|l|}{ Energy for lighting is in class A. } & 5 \\
\hline D1.5 & \multirow{2}{*}{$\begin{array}{l}\text { Energy for appliances } \\
\text { To minimise energy needs for appliances. }\end{array}$} & & $12.82 \%$ \\
\hline Intent & & Score & Weight \\
\hline Indicator & \multicolumn{3}{|c|}{$\begin{array}{l}\text { Using electric appliances with low consumption of electric energy, which is } \\
\text { determined by energy class. }\end{array}$} \\
\hline Negative & \multirow{2}{*}{\multicolumn{2}{|c|}{$\begin{array}{l}\text { At least one electric appliance is in energy class lower than A or B. } \\
\text { Fewer than } 2 / 3 \text { of electrical appliances are in energy class } A \text {, the } \\
\text { others are in B. }\end{array}$}} & -1 \\
\hline Acceptable practice & & & 0 \\
\hline Good practice & $\begin{array}{l}\text { At least } 2 / 3 \text { of electrical appliances are in energy class A a } \\
\text { in B. }\end{array}$ & ind $1 / 3$ is & 3 \\
\hline Best practice & All electrical appliances are in energy class A. & & 5 \\
\hline D2 & Active systems using renewable energy sources & & $25 \%$ \\
\hline D2.1 & Solar system and/or photovoltaic technology & & $36 \%$ \\
\hline Intent & $\begin{array}{l}\text { To minimise energy consumption by using active solar } \\
\text { components or photovoltaic technology. }\end{array}$ & Score & Weight \\
\hline Indicator & $\begin{array}{l}\text { Using solar energy for domestic hot water and heating o } \\
\text { electric energy. }\end{array}$ & transforn & nation to \\
\hline Negative & Solar system and/or photovoltaic technology is not installed & & -1 \\
\hline Acceptable practice & $\begin{array}{l}\text { Energy generated by solar system and/or photovoltaic te } \\
\text { covers }<30 \% \text { of energy consumption. }\end{array}$ & chnology & 0 \\
\hline
\end{tabular}


Table 8 continued

\begin{tabular}{|c|c|c|}
\hline Good practice & $\begin{array}{l}\text { Energy generated by solar system and/or photovoltaic technology } \\
\text { covers } 30-60 \% \text { of energy consumption. }\end{array}$ & 3 \\
\hline Best practice & $\begin{array}{l}\text { Energy generated by solar system and/or photovoltaic technology } \\
\text { covers }>60 \% \text { of energy consumption. }\end{array}$ & 5 \\
\hline D2.2 & \begin{tabular}{|l|l} 
Technology for renewable energy other than solar energy & \\
\end{tabular} & $32 \%$ \\
\hline Intent & \begin{tabular}{l|l} 
To minimise energy consumption by using technology for \\
renewable energy sources other than solar energy.
\end{tabular} & Weight \\
\hline Indicator & \multicolumn{2}{|c|}{$\begin{array}{l}\text { Using renewable energy other than solar energy for domestic hot water and } \\
\text { heating/cooling or transformation to electric energy. }\end{array}$} \\
\hline Negative & \multirow{2}{*}{$\begin{array}{l}\text { Technology for renewable energy is not installed. } \\
\text { Renewable energy other than solar energy for domestic hot water } \\
\text { and heating/cooling or transformation to electric energy covers } \\
<30 \% \text { of consumption energy. }\end{array}$} & -1 \\
\hline Acceptable practice & & 0 \\
\hline Good practice & $\begin{array}{l}\text { Renewable energy other than solar energy for domestic hot water } \\
\text { and heating/cooling or transformation to electric energy covers 30- } \\
60 \% \text { of consumption energy. }\end{array}$ & 3 \\
\hline Best practice & $\begin{array}{l}\text { Renewable energy other than solar energy for domestic hot water } \\
\text { and heating/cooling or transformation to electric energy covers } \\
>60 \% \text { of consumption energy. }\end{array}$ & 5 \\
\hline D2.3 & \begin{tabular}{|l|l} 
Heat recuperation & \\
\end{tabular} & $32 \%$ \\
\hline Intent & \multirow{2}{*}{ To utilise recovery heat. } & Weight \\
\hline Indicator & & \\
\hline Negative & Heat recuperation is not utilised. & -1 \\
\hline Acceptable practice & Under $30 \%$ of recovery heat is utilised for heat recuperation. & 0 \\
\hline Good practice & $30-60 \%$ of recovery heat is utilised for heat recuperation. & 3 \\
\hline Best practice & Above $60 \%$ of recovery heat is utilised for heat recuperation. & 5 \\
\hline D3 & \begin{tabular}{|l|l} 
Energy management &
\end{tabular} & $18.75 \%$ \\
\hline D3.1 & Energy management system & $50 \%$ \\
\hline Intent & To improve the energy performance of a building. & Weight \\
\hline Indicator & \multicolumn{2}{|l|}{ Utilising an energy management system according to ISO 50001.} \\
\hline Negative & No energy management system is established for the building. & -1 \\
\hline Acceptable practice & $\begin{array}{l}\text { Requirements specified in standard for energy management system } \\
\text { are } 50 \% \text { met. }\end{array}$ & 0 \\
\hline Good practice & $\begin{array}{l}\text { Requirements specified in standard for energy management system } \\
\text { are } 75 \% \text { met. }\end{array}$ & 3 \\
\hline Best practice & $\begin{array}{l}\text { Requirements specified in standard for energy management system } \\
\text { are } 100 \% \text { met. }\end{array}$ & 5 \\
\hline D3.2 & \begin{tabular}{|l|l} 
Facility management & \\
\end{tabular} & $50 \%$ \\
\hline Intent & To improve performance of systems in the building. & Weight \\
\hline Indicator & \multicolumn{2}{|c|}{$\begin{array}{l}\text { Utilising facility management system according to EN } 15221 \text { series of } \\
\text { standards. }\end{array}$} \\
\hline Negative & System of facility management is not established for the building. & -1 \\
\hline Acceptable practice & $\begin{array}{l}\text { Requirements specified in standard for facility management are } \\
50 \% \text { met. }\end{array}$ & 0 \\
\hline Good practice & $\begin{array}{l}\text { Requirements specified in standard for facility management are } \\
75 \% \text { met. }\end{array}$ & 3 \\
\hline Best practice & $\begin{array}{l}\text { Requirements specified in standard for facility management are } \\
100 \% \text { met. }\end{array}$ & 5 \\
\hline
\end{tabular}


can see that the approaches of assessment are essentially not that different. Several differences are found in the terminology, but different indicators in the systems are often evaluated under similar headings. Classification and certification of buildings differ from one country to another in accordance with national conditions and requirements. The sensitivity of methods and independence of indicators are progressively ensured with continuous modification and specification of methods and tools. It, therefore, follows that good building environmental assessment requires a multidisciplinary and multi-criteria approach.

The developed building environmental assessment system applicable in the conditions of Slovakia consists of 6 main fields and 52 indicators and incorporates systems and methods used in many other countries. The main fields are building site and project planning, building constructions, the indoor environment, energy performance, water management and waste management.

The main features of the system include the following:

- BEAS is a multi-criteria system and includes environmental, social and cultural aspects;

- the evaluated indicators respect European and Slovak standards, rules, studies and experiments;

- the system allows the establishment of indicator weights that reflect their varying importance in the region;

- designers can specify targets for building performance in terms of various aspects;

- assessors can accept the assessment made by designers.

Based on the comparison of the main fields in BEAS, it is possible to assert that the field of energy performance has the highest percentage weight significance $(26.45 \%)$. The percentage weights of others fields are $14.71 \%$-site selection and project planning, $20.59 \%$-building construction, $23.49 \%$-indoor environment, $8.88 \%$-water management and $5.88 \%$-waste management.

The theoretical level of existing knowledge about building environmental assessment has been thoroughly analysed and applied, making it necessary to implement this knowledge in construction practice. For the purpose of system verification, a statistically significant set of buildings needs to be evaluated, the outcome of which will be modification of the fields and indicators weighting. Our future research work will be an implementation of aspects and indicators given in European standards for the sustainability assessment of buildings to the BEAS applicable in Slovakia and a comparison of BEAS with significant and globally used building environmental assessment systems.

Acknowledgments This study was supported by European Union Structural Funds (Grant code: ITMS 26220120037, ITMS 26220220064) and the Grant Agency of Slovak Republic for the support of projects no. 1/0405/13, on the basis of which these results are presented.

Conflict of interest The authors declare that they have no competing interests.

Authors' contributions SV has participated in preparing the state of the art of energy performance of buildings, proposal of indicators of energy performance field. EKB used the MCDA for determination of significant weights and evaluating of indicators of energy performance field. Together with SV evaluated the results from MCDA and processed conclusion. All authors read and approved the final manuscript.

Open Access This article is distributed under the terms of the Creative Commons Attribution License which permits any use, distribution, and reproduction in any medium, provided the original author(s) and the source are credited.

\section{References}

1. Akadiri, OP: ICT Development of a multi-criteria approach for the selection of sustainable materials for building projects. Dissertation, University of Wolverhampton (2011)

2. Hui, S.C.M.: Low energy building design in high density urban cities. Renew. Energy 24, 627-640 (2001)

3. Anglani, N., Muliere, G.: The impact of renewable energy and energy efficient technologies, what to choose in case of limited supportive actions: a case study. Int. J. Energy Environ. Eng. 2(4), 83-94 (2011)

4. Flodberg, K., Blomsterberg, Å., Dubois, M.C.: Low-energy office buildings using existing technology: simulations with low internal heat gains, Int. J. Energy Environ. Eng. 1-9, http://www. journal-ijeee.com/content/3/1/19 (2012). Accessed 24 Jan 2014

5. Krídlová Burdová, E., Vilčeková, S.: Building environmental assessment system in Slovakia, p. 124 (2013)

6. Merola, S.S., Tornatore, C., Marchitto, L., Valenteno, G., Corcoine, F.E.: Experimental investigations of butanol-gasoline blends effects on the combustion process in a SI engine. Int. J. Energy Environ. Eng. 3(6), 1-14 (2012)

7. Chenicheri, C.S., Chandrasekharan, M., Palatel, A.: Life cycle assessment of producer gas derived from coconut shell and its comparison with coal gas: an Indian perspective, Int. J. Energy Environ. Eng., http://www.journal-ijeee.com/content/4/1/ (2013). Accessed 24 Jan 2014

8. Ondova, M., Stevulova, N.: Slovak fly ash as cement substitution in the concrete road pavements, p. 99 (2013)

9. Ondova, M., Stevulova, N.: Environmental assessment of fly ash concrete. Chem. Eng. Trans. 35, 841-846 (2013)

10. Parliament, European: Council of the European Union: directive 2010/31/EU of the European Parliament and of the Council of 19 May 2010 on the energy performance of buildings. Off. J. Eur. Union 53, 13-35 (2010)

11. Brouwerw, H.J.H., Reinder, A.H.M.E.: Evaluation of energy performance indicators and the financial aspect of energy saving techniques in residential real estate. Energy Build. 42, 618-629 (2010)

12. Hoesen, J., Letendre, S.: Evaluating potential renewable energy resources in Poultney, Vermont: a GIS-based approach to supporting rural community energy planning. Renew. Energy 35, 2114-2122 (2010)

13. Míguez, J., et al.: Review of the energy rating of dwellings in the European Union as a mechanism for sustainable energy. Renew. Sust. Energy Rev. 10, 24-45 (2006) 
14. Pérez-Lombard, L., et al.: A review of HVAC systems requirements in building energy regulations. Energy Build. 43, 255-268 (2011)

15. BREEAM. BREEAM new construction. Non-domestic buildings. Technical manual. SD5073-2.0:2011 http://www.breeam.org/ BREEAM2011SchemeDocument (2011). Accessed 24 Jan 2014

16. CASBEE. CASBEE ${ }^{\circledR}$ for new construction. Technical manual (2010 Edition). Japan Sustainable Building Consortium (2010)

17. Cole R.J., Rousseau D., Theaker, G.T.: Building environmental performance assessment criteria (BEPAC) (1993)

18. LEED 2009 for new construction and major renovations. For public use and display. USGBC Member Approved November 2008 (Updated November 2011) (2011)

19. BEAM Plus. BEAM Society. Building environmental assessment method. NB-new buildings, p. 219, (2009)

20. Hikmat, H.A., Saba, F.A.N.: Developing a green building assessment tool for developing countries - case of Jordan. Build. Environ. 44, 1053-1064 (2009)
21. Estidama. The Pearl Rating System for Estidama. Community rating system. Design and construction. http://estidama.org/ Accessed 24 Jan 2014

22. Ding, G.K.C.: Sustainable construction: the role of the environmental assessment tool. J. Environ. Manag. 8(1), 451-464 (2008)

23. Seo S. et al, Technical Evaluation of Environmental Assessment Rating Tool, http://www.fwpa.com.au/sites/default/files/PN05. 1019.pdf (2005). Accessed 24 Jan 2014

24. Yang, Y., Li, B., Yao, R.: A method of identifying and weighting indicators of energy efficiency assessment in Chinese residential buildings. Energy Policy 38, 7687-7697 (2010)

25. Saaty, T.L.: Decision making with the analytic hierarchy process. Int. J. Serv Sci 1(1), 83-98 (2008)

26. Říha, J.: Multicriteria analysis, p. 67 (2002) 